\title{
PIN1 Gene
}

National Cancer Institute

\section{Source}

National Cancer Institute. PIN1 Gene. NCI Thesaurus. Code C120048.

This gene plays a role in the regulation of the post-phosphorylation conformation of protein substrates. 